\title{
Plants as Machines: History, Philosophy and Practical Consequences of an Idea
}

\author{
Sophie Gerber ${ }^{1} \cdot$ Quentin Hiernaux $^{2,3}$ D
}

Accepted: 21 December 2021

(c) The Author(s), under exclusive licence to Springer Nature B.V. 2021

\begin{abstract}
This paper elucidates the philosophical origins of the conception of plants as machines and analyses the contemporary technical and ethical consequences of that thinking. First, we explain the historical relationship between the explicit animal machine thesis of Descartes and the implicit plant machine thesis of today. Our hypothesis is that, although it is rarely discussed, the plant machine thesis remains influential. We define the philosophical criteria for both a moderate and radical interpretation of the thesis. Then, assessing the compatibility of current botanical knowledge with both interpretations, we find that neither withstands scrutiny. We trace how biological and agricultural sciences have historically relied upon thinking of plants as machines and how they continue to do so today through rhetoric centred on breeding, biotechnology, and production. We discuss some of the most important legal and ethical consequences of obscuring the vitality of plants. Finally, we explore less reductive and destructive ways of thinking about, and using, plants.
\end{abstract}

Keywords Plant $\cdot$ Machine $\cdot$ Ethics $\cdot$ Philosophy $\cdot$ Agriculture $\cdot$ Biology

\section{General Introduction}

Today, few apply Descartes' notorious view of organisms as machines to vertebrates. However, it seems to be the default view about non-vertebrate organisms, especially plants.

Against this backdrop, in this paper, we will look first at the historical and philosophical origins of the plant machine thesis. We will then study whether plants lack

Quentin Hiernaux

quentin.hiernaux@ulb.be

1 BIOGECO, INRAE, Univ. Bordeaux, 33615 Pessac, France

2 Department of Philosophy, Ethics and Religious Sciences, PHI, National Fund for Scientific Research-FNRS, University of Brussels, Brussels, Belgium

3 Écoles des Hautes Études en Sciences Sociales (EHESS), Institut Jean-Nicod, Paris, France 
sensitivity (following a more radical thesis), and question their lack of ratiocinative and intellective faculties (as per a more moderate thesis). Next, we will examine how certain conceptions of biology, farming techniques, and biotechnology cohere with the legacy of the plant machine thesis. Finally, we will consider the contemporary ethical implications of the agricultural and technological treatment of plants as machines.

How does the idea of the plant as machine express itself? Why does it remain widely assumed? How is it present in plant sciences, particularly in agriculture? By answering these questions, we will address the plant machine ideology, along with the theoretical and practical issues surrounding it. We conclude by proposing alternatives to our societal thinking about plants and our relationships with them.

\section{The Plant Machine: An Introduction}

In general, the term 'plants' refers to all autotrophic photosynthetic taxonomic groups: algae, mosses, ferns, seed plants and flowering plants. However, in this paper, and the literature it engages with, the term 'plant' refers primarily to terrestrial, and most often vascular, plants.

A machine can be defined as a 'complex manufactured object capable of transforming one form of energy into another and/or capable of using this transformation to produce a given effect, to act directly on an object to modify it according to a fixed goal.' ${ }^{1}$ Thus, a machine is a complex assembly of elements which, unlike a tool, functions in a relatively autonomous way, but whose functions and activities are predetermined by its goals. The organism machine thesis assumes that nonhuman behaviour depends on purely mechanical reflexes, and, therefore, the nonhuman organism reacts automatically, like a machine.

In the second half of the twentieth century, philosophers developed a broader machine concept. In Simondon (1958), for example, the machine is a technical individual always associated with a 'milieu' which makes its functioning possible. Guattari (1993) revises this idea by articulating the notion of the 'machinic arrangement' (agencement machinique), which posits that the machine's operations depend not only on its association to a material environment, but also to a political, cultural, biological and linguistic organization. Hence, the machine is not only technical, but also integrated into the operation of society as a whole (Sauvagnargue, 2012).

In the first part of this paper, the machine is to be understood in its historical sense. However, viewing our relationship to plants as a machinic arrangement is a good way to exemplify the socio-economic dimension of the agricultural, technoscientific organization discussed in the latter parts of the paper.

\footnotetext{
1 'Machine', CNRTL, Centre national de Ressources textuelles et lexicales. Retrieved October 18, 2021, from: https://www.cnrtl.fr/definition/machine. Author's translation.
} 


\section{Historical and Philosophical Origins of the Plant Machine}

In this section, we discuss the philosophical dimension of the view of the organism as a machine, from the sixteenth century onwards. We show how the animal machine thesis, while criticized since its origins, has nevertheless continued to condition our relationship to plants.

The term 'animal machine' may be traced back to Cartesian philosophy (Descartes, 1637, V, 9, Descartes, 1649), and is familiar to historians of philosophy and biology, as well as to animal welfare advocates (Guichet, 2010). Descartes' original notion of animals as natural machines eventually broadened to include plants as well. Terminology which frames organisms as machines is less prevalent in contemporary biology publications, though it occasionally surfaces in works concerning the role of animals in farming. Despite being more relevant to the study of history, the idea of organism as machine is nevertheless useful for understanding our contemporary relationship to plants. According to François Delaporte:

The mechanism of vegetation is far more secret and obscure than that of animals [...]. If the mechanism of plants can be grasped only to the extent that it reflects what is already known about the mechanism of animals, however, it follows that the animal world is to plant physiology as the technological world is to animal physiology. Ultimately this comes to the same thing as saying that the technological world, via animal physiology, structures the perception of plant phenomena. (Delaporte, [1979], 1982: 28)

Recognizing the philosophical foundations of the animal machine thesis-and the more general organism machine thesis it inspired-offers insight into the contemporary consequences of plant mechanization (Pouteau, 2014).

In Cartesian dualism, the body is a spatially extended physical substance, while the mind is an immaterial, mental substance distinct from any organic body. On Descartes' account, only humans possess this mental substance. Known as res cogitans, the mental gives humans their subjectivity and interiority. By contrast, extended physical substance, known as res extensa, makes up the world of objects (Descartes, 1647, Sects. 51-54). According to Descartes, only human beings are endowed with souls, and, with them, consciousness, reason and emotion. His theory of the animal machine states that all other animals are nothing beyond their bodies, reducing them to soulless machines that simulate life through movement, but are devoid of any genuine consciousness or intellectual faculties. Descartes explains animal behaviour entirely in terms of reflexes, contrasting such mechanical reactions with human reason, and, thereby, justifying animal vivisection (Descartes, 1637, Part V; Descartes, 1646). In a way, 'Descartes does for the animal what Aristotle did for the slave: he disqualifies it to justify man to use it as an instrument' (Canguilhem, 1965 cited in Pouteau, 2014). Descartes' view became famous, but was never unanimously adopted among philosophers or naturalists, who were sometimes 
struck by the closeness of animal and human behaviour (Gaukroger, 1995). ${ }^{2}$ Already in the sixteenth century, Montaigne argued in favour of an ethical position acknowledging the value of all organisms: 'there is nevertheless a certain respect, a general duty of humanity, not only to beasts that have life and sense, but even to trees, and plants' (Montaigne, 1580, II chap. XI). Other contemporaries of Descartes were sceptical of his practice of vivisection and its philosophical justifications (GeorgesBerthier, 1914). ${ }^{3}$ Everyday observations of dogs, horses, chickens and other farm animals suggest that they react, think and suffer in ways comparable to humans. But ideology eclipsed observation for Cartesian successors like Malebranche (1638-1715). He would rely on the animal machine thesis to deny animals emotion, the ability to suffer, and claims to moral standing (Allen \& Trestman, 2020; Olson, 1990: 39-40). Until the nineteenth century, nonhuman animals were often treated as objects because they supposedly lacked certain human characteristics (Francione, 2000: 1-2; Burgat, 2006). However, other philosophers of the modern era criticized this ontological and moral distinction between animal and human. Condillac recognized sensation in animals, as well as judgment and memory (Condillac, 1792: 309-385; Kreutzer, 2017: 25), and paid particular attention to plants (Bertrand, 2020b). John Locke went so far as to suggest that animals such as parrots-which he took to exhibit rational behaviour through language-could be endowed with an immaterial mind and thus with consciousness (Locke, 1690, chap. 27 Sect. 8).

In the twentieth and twenty-first centuries, advances in (neuro)biology and a radically different conception of the mind-body relation seemed to rule out the animal machine thesis (Andrews, 2016). Even though debates continue about the nature of animal consciousness, sentience or reasoning, these abilities are fully recognized in some so-called higher animals. However, there remains a tendency to appeal to the mechanistic conception of organisms concerning most invertebrates or other 'lower' organisms. Thus, when the distant kingdom of plants is considered, it is easy to slip into mechanistic thinking. Historically, such assumptions are not controversial. Unlike vertebrates, plants have not stirred the passions of philosophers or citizens disturbed by the cruelty of their fellows toward other species.

\section{Context and Methods}

Considering the distinction between traditional and contemporary approaches to the organism as machine, and in view of the absence of an explicit theory of the plant as machine, we characterize here the theoretical elements which constitute this view.

Synthesizing the literature on the organism machine thesis (Allen \& Trestman, 2020; Andrews, 2020; Andrews \& Monsó, 2021; Aydede, 2019; Burgat, 2006, 2020; Francione, 2000; Gruen, 2021; Guichet, 2010; Kreutzer, 2017; Renck \& Servais, 2002; Scarantino and de Souza, 2021; Uexküll, [1934], 1965), let's distinguish a

\footnotetext{
2 In 1706, the Jesuits condemned the Cartesian thesis that animals do not have souls.

3 Descartes himself practiced vivisection and justified it by his mechanical conception of life (Descartes, Letter to Plempius, February 15, 1638).
} 
radical, rather dated version of the organism-machine thesis from a moderate, more contemporary version.

For non-human living beings, the moderate version rejects:

(1) Reason and intellectual faculties

(2) Self-consciousness

(3) Moral standing

In addition to these three items, the radical version also denies to non-human living beings:

(4) Sensitivity and suffering

(5) Valenced sensations ${ }^{4}$ and emotions

We will evaluate how, and to what end, these theses apply to plants. The five elements refer to concepts with a vast extension and multiple meanings. In our study, each can be defined as follows, keeping with their use in the aforementioned literature and philosophical dictionaries (Blay, 2012; Lalande, 1996):

(1) Reason and intellectual faculties encompass logical reasoning, mental representation, language and a general capacity for abstraction.

(2) Self-consciousness involves the faculty to know oneself (as in Descartes' cogito ergo sum). This was often considered the highest expression of consciousness, and one unique to humans.

(3) Humans attribute moral standing to humans or other entities which are believed to merit protection from harm, and are subjects and objects of moral responsibilities or duties. Excluding certain organisms from the moral sphere is not universally acknowledged as an integral component of the organism machine thesis, but it may be a logical consequence of that thesis.

(4) Suffering is the ability to feel physical pain. It is linked to sensitivity: the faculty to perceive and to detect stimuli from the external world. ${ }^{5}$

(5) Valenced sensations are experiences which are perceived by the subject as either desired or undesired. Emotion refers to subjective, internal and abstract expressions correlated to external events and valenced sensations.

The claim that these two versions of the organism machine thesis are, respectively, radical or moderate, is not absolute, but relative. First, one version is more radical than the other merely due to its broader scope: it includes the same basic criteria as the moderate version with further, more restrictive, conditions. Second, the radical or moderate character of these two versions must be evaluated and judged

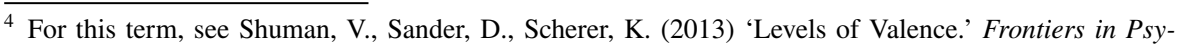
chology, 4, 261.

5 Sensitivity is a necessary condition for feeling pain, but it is not a sufficient one. Thus, a mechanical sensor, although it is a stimulation detection tool, does not suffer. For some philosophers, perception is the ordering of raw sensations, hence an interpretation or a minimal representation of the world. In this sense, a mechanical sensor is sensitive but not necessarily perceiving. However, this technical debate goes beyond our present conceptual framework.
} 
extrinsically to the kinds of organisms to which they claim to apply. Rejecting even one of these five premises is sufficient to challenge both the radical and the moderate organism machine theses.

\section{Plant Machine and Plant Faculties}

Against the radical and moderate animal machine theses, animal ethicists cite animal sensitivity and rationality as the two main criteria which justify including nonhuman animals in the moral sphere. In the next two sections, we asses whether the same reasoning can be applied to plants.

\section{Sensitivity and Pain}

The Western tradition has usually treated plants with the radical version of the organism machine thesis.6 At least since Aristotle's treatise On the Soul (350 B.C.), the soul has been considered the distinguishing mark of the living things. According to Aristotle and his intellectual descendants, any life is ruled by a soul, a principle of movement that expresses itself differently in plants, nonhuman animals and human beings. In the West, it has been widely maintained that only humans are endowed with reason and sensibility by virtue of the rational and the sensitive faculty of their souls. On the other hand, animals perceive but are not rational, and plants have neither senses nor rationality. Plants were thought to possess only the vegetative faculties of the soul, shared with animals and humans, which afforded them the abilities of nourishment, growth and reproduction. ${ }^{6}$ Aristotle's ideas were prevalent among naturalists and philosophers from the Middle Ages even into the twentieth century. The physician, philosopher and botanist Julien Offray de la Mettrie (1709-1751) expressed the view explicitly:

The plant is rooted in the earth which nourishes it, it has no needs, it fertilises itself, it does not have the faculty of moving and it has been regarded as an immobile animal which however lacks intelligence and even feeling. [...] [Plants] experience neither pain nor pleasure. How evenly balanced everything is! They die as they have lived, without feeling it. It would not have been fair for those who live without pleasure to die in pain. (La Mettrie, 1748: 83-84)

Here, the plant is described as passive, insensitive, immobile, non-animal, inferior, soulless - it is close to the mineral world, and, thus, belonging strictly to the material domain like other objects. La Mettrie also establishes a causal link between, on the one hand, the number of a thing's needs and, on the other, the

\footnotetext{
${ }^{6}$ Western philosophers and theologians mostly considered plant souls to be mortal, whereas the immortality of animal souls was the subject of some debate.
} 
quantity of motion and intelligence necessary to satisfy them. Immobile plants, having no needs, have, therefore, no intelligence. Moreover, he vigorously rejects the possibility of affective ('feeling') capacities for plants, even in their simplest expression of desire or pain like valenced sensations. For La Mettrie, we no more need to posit a soul to explain the growth of a plant than we do to explain the merely slower growth of a stone. Although he was a botanist, he viewed plants through the strongly physical materialist lens which emerged in the modern era.

A few years later, in his Reveries (written between 1776 and 1778 [1972]:130), philosopher and botany enthusiast Jean-Jacques Rousseau referred to the plant as an 'object' or a 'living machine'. This idea was widely shared by botanists and philosophers of the modern period (Delaporte, 1979). Carl von Linné, the naturalist credited with introducing the binomial nomenclature for species that is still in use today, also declared the insensitivity of plants (Linné, 1736, aphorisms 3 and 133).

The rejection of plant sensitivity in favour of the plant machine thesis can be explained by the confusion between sensitivity and suffering. Unlike an animal, a plant faced with injury neither expresses suffering, nor avoidance behaviour-at least from what the human eye can tell. Likewise, physiological approaches have shown that, unlike animals, plants do not have a nervous system, a discovery which reinforced the traditional idea that they do not suffer, or even that they are insensitive. This conception persisted in the nineteenth and twentieth centuries (Hiernaux, 2019). It was supported by the reasoning that if suffering is not conspicuous in plants, it does not exist-a view often shared by today's biologists or philosophers, who consider the nervous system to be a necessary condition for the ability to feel pain. According to certain philosophers, including contemporary ones (for example, Burgat, 2020), if plants fail to react to their environment as our own subjectivity would have us do, their internal life is demonstrably absent. Therefore, they can be equated with machines — objects deprived of feeling and emotion-and stripped of moral status. Some contemporary authors have views of plants that are surprisingly close to those of La Mettrie two hundred years ago. By contrast, since vertebrate animal reactions are interpreted as demonstrating some subjectivity, they are not as often straightforwardly relegated to the realm of objects.

Yet, plants' lack of a nervous system and of an outward expression of suffering should neither convince us of their insensitivity nor lead to their definitive exclusion from any moral consideration. Since the second half of the nineteenth century, physiological experiments have shown the existence of non-nervous chemical and electrical sensitivity in plants (Bernier, 2013). Indeed, plants have been found to perceive and respond to stimuli in their environment, mainly through chemical messages (Trewavas, 2014). Therefore, even if plants do not suffer, their sensitivity cannot be denied, as it can be objectively established and measured.

However, this does not yet prove the presence of emotions or consciousness in plants. As subjective phenomena, these cannot be observed, but only indirectly deduced from outward expressions. Ethologists generally agree that emotion or consciousness depends on a rather high level of mental organization, which seems to be present only in a brain. Plants probably do not have any equivalent organization. However, not everyone shares this view of internal, subjective states (Trewavas et al., 
2020). We cannot take for granted that consciousness, emotion, or other subjective states can only be inferred from the presence of particular biological structures that are considered exclusively necessary for these states (Hiernaux, 2021a, 2021b).

In any case, recognizing that plants have adaptive reactions to stimuli which are not predetermined reflexes is sufficient to reject the radical interpretation of the plant machine thesis. Although we will not resolve the debate on plant emotions or consciousness here, we question the assertion that plants are devoid of any form of reason. Indeed, certain biologists and philosophers defend a kind of plant intelligence which may overlap with rational aspects of behaviour (Debono, 2020; Hiernaux, 2020; Maher, 2017; Mancuso \& Viola, 2015; Trewavas, 2014). If these researchers are right, even the moderate version of the organism machine thesis- the one which denies plants any kind of intellectual faculty—should be rejected.

\section{Non-human Rationality}

Several influential modern Western philosophers, including Descartes and Kant, have judged reason to be specific to humans. For them, reason was defined by selfconsciousness, together with the use of language, concepts and mental representations. So defined, reason obviously cannot be attributed to plants-but neither can it be attributed to most non-human animals. On the other hand, other characterizations of rationality which do not deny reason to non-human animals could plausibly also not deny it to plants either.

Another definition of reason is as an organism's ability to implement problemsolving strategies over its lifetime and to use experiences to adapt to environmental changes. Contemporary advocates of plant intelligence have defended the existence of this kind of instrumental rationality (Kolodny \& Brunero, 2020) in plants (Trewavas, 2014; Mancuso, 2015). Theories of minimal cognition which apply to plants (and even to bacteria) likewise identify cognition with an organism's ability to access and process information from its environment or to regulate its own biological behaviours through decision processes (Maher, 2017; Hiernaux, 2021a, 2021b; Bechtel \& Bich, 2021).

Even if they do not master the laws of logic, many animals are able to make useful inferences for solving problems. Similarly, they can generalize from remembered past experiences to react more efficiently and effectively to new circumstances (Cvrcková et al., 2009). Animals can even use tools to achieve goals (Andrews, 2016). These behaviours demonstrate a kind of animal rationality which does not rely on self-consciousness or metacognition - that is, on the ability to think about one's own mental states or the mental states of others (Carruthers, 2008). If it is appropriate to call this 'non-self-conscious rationality', we can accept that instrumental reason is a sign of rationality or of intelligence. Then, we may consider how plant behaviour might potentially demonstrate reason.

Like animals, plants demonstrate learning and memory (Thellier, 2015; Trewavas, 2014). Plants can react more effectively to certain stimuli, including predator attacks or other stresses, after they have already been confronted with them in the past (Sultan, 2015). Plants' ability to anticipate previously experienced situations 
seems to demonstrate their habituation and even stimuli-associated learning (Gagliano et al., 2014, 2016).

If tools are conceived of as bodily extensions intended to fulfil objectives, then climbing plants make use of tools. They actively seek out supports, around which their stems, roots or tendrils cling or wrap. These supportive tools greatly facilitate plants' goals of growth and their search for light (Trewavas, 2014, chap. 9). Recent experiments demonstrate that the nutation movement of pea plants is neither linear nor purely endogenous because it is influenced by the presence of a distant pole. Peas are seen to detect the support before touching it and to adapt their movements to its presence in a complex way, suggesting that the biological control of nutation is guided by relevant environmental factors like the pole (Raja et al., 2020). Moreover, pea tendrils adapt to the pole's thickness before touching it by modifying their velocity (Guerra et al., 2019; Simonetti et al., 2021). The process by which plants choose tools may be described as a sign of instrumental rationality, which, in turn, undermines the moderate interpretation of the plant machine thesis. As Darwin (1865) pointed out, plant actions such as the seeking behaviours of vines cannot be equated with simple predetermined reflexes as they vary by context.

\section{Plant Machine, Biology and Farming Techniques}

In this section, we intend to show the continuous influence of the plant machine thesis on the development of plant sciences. This influence can be seen primarily at the theoretical level (Sect. 4.1), but also in political and economic discourses about agriculture, which exhibit strong and highly technical relationships with plants (Sects. 4.2 and 4.3). However, both the radical and moderate versions of the plant machine thesis have been shown to be theoretically limited. Additionally, certain historical Western relationships with plants result today in ethical and legal attitudes that must be questioned, because of their environmental consequences (Sect. 5). Therefore, we propose an unbiased reinvention of human-plant relationships, on philosophical, scientific and practical levels.

\section{Plant Scientific View and Machine}

The philosophical view of the plant as a machine, which emerged in the modern era, had consequences for contemporary Western science. The effects are of two, closely related, kinds: theoretical and ethical (Pouteau, 2014). In the life sciences, the observations of naturalists were so heavily biased by the conception of an insensitive and immobile plant that, for a long time, they could hardly be described as observing at all. In the sixteenth and seventeenth centuries, scientists rarely bothered to observe the movements or reactions of plants, which were assumed to be non-existent. Contemporary biology studied these phenomena through phenotypic ${ }^{7}$ plasticity (like

\footnotetext{
7 Phenotype: the observable characteristics of an organism, determined by the interaction between its genotype and environmental factors.
} 
changes in behaviour, morphology and physiology in a specific environment) and reaction norms (the pattern of the phenotypic expression of a single genotype across a range of environments). Relevant here is the allegory of the person who, having lost something in the night, looks for it under a streetlamp because that's where the light is. The rare observations which uncovered plant actions (see Delaporte, [1979] 2011; Hiernaux, 2019) were considered exceptional and, generally, their results were attributed to the influence of surrounding environments: the passive and inert plant must not really move but must instead be moved by external physical forces. For instance, Descartes developed a theoretical conception of life organized around the principle that heat sustains the heart as a motion-like principle (Bitbol-Hesperiès, 1990). But he failed to notice that to base the idea of life on uniquely animal characteristics such as heat, heart and blood was simply to deny plant life. Thus, one of the most significant philosophers of his time and of our philosophical and scientific tradition arbitrarily ostracized plants. ${ }^{8}$ A lack of sufficient scientific knowledge of plant anatomy and physiology cannot explain the philosopher's position. First, no detailed scientific knowledge was required to find that plants do not produce heat. Second, the problem of turning plants into machines was raised sixteen years before Descartes' birth by the famous botanist, zoologist and plant anatomy pioneer Andrea Cesalpino (1524-1603), who even referred to an analogy of animals as machines:

In animals we see that food is carried through the veins to the heart like toward a workshop which produces the inner heat. Once the food has been completely processed, it is distributed by the arteries throughout the body by the action of the breath, which is itself produced in the heart by the same food. But in plants we see no veins or other visible channels, and we perceive no heat. We may therefore wonder how trees grow to such a great size, when they seem to contain much less heat than animals. (Cesalpino, 1583: 3-4)

According to Cesalpino, sensitivity, movement and growth require heat. This led him to claim that plants produce an innate, inconspicuous heat. This point, linking heat and the life principle, remained central to the views of many modern philosophers at least until Hegel (1830).

As it helped to make apparent sense of several plant phenomena, the Cartesian mechanistic view was quite successful from the seventeenth century onwards. Several plant physiologists, including Mariotte (1620-1689), endorsed Descartes' view and undertook the study of plant nutrition on mechanistic grounds, rejecting the idea of a vegetative soul as the principle of life. Mariotte observed that the chemical composition of plants varied depending on species, and differered also from that of the ground. Other scientists took similar approaches towards botany: Robert Sharrock (1630-1684) worked on grafting and the phototropism of stems in 1660; Denis Dodart (1634-1707) studied respiration, growth and the geotropism of roots

\footnotetext{
${ }^{8}$ Descartes' interest in plants is evidenced in at least two places in his work (Primae cogitationes circa generationem animalium (AT XI 534-535) and Excerpta antomica (AT XI 627-629)). However, he did not seem to integrate them into his more general theories about life in any systematic way (Baldassarri, 2019).
} 
in 1700; John Ray (1627-1705), Stephen Hales (1677-1761) and Marcello Malpighi (1628-1694) worked on sap circulation, on pressure and sucking plant forces linked to fluid movement (Davy de Virville \& Leroy, 1969a, 1969b). Although their discoveries helped to bolster the plant machine thesis, other discoveries in reproduction and plant physiology pushed in the opposite direction. Therefore, the strong popularity of the plant machine thesis could not have been strictly scientific but more broadly ideological. For example, in 1732, the botanist Boerhaave claimed that 'plants are only machines and are not alive. By plant we mean a hydraulic body' (Boerhaave quoted by Delaporte, [1979], 1982: 84). However, in 1773, botanist Bernardin claimed that a tree 'is not an ingenious arrangement of pumps and pipes where the sap runs up and down' (Bernardin de Saint-Pierre quoted by Benharrech, 2022). Yet, the mechanistic interpretation still seems to prevail today.

The success of the mechanistic explanation can be accounted for by both pragmatic and ideological reasons. We hypothesize a feedback loop: the perception of plants as machines encouraged shaping plants to be more machinelike. The technological links between agriculture and the biological sciences in contemporary Western society has significantly contributed to forging the idea of plants as machines, as simple technical objects, products, or non-individualized resources (Dagognet, 1988).

In the second half of the eighteenth century, the physiocrats declared the establishment of an economic science based on the then-emerging field of botany (Larrère, 1992). The multi-faceted, diverse vision of wheat, and its association with peasant culture across the wide variety of environments in which it grew, together with its importance in the lives of the people and animals who worked with it, was replaced by the narrative of mere plant 'production'. François Quesnay, the founder of the physiocratic movement, conceived of plant production as a simple equation which followed the laws of physics. This thinking broke from the peasant tradition: wheat became little more than a universal currency in the system of exchanges, a transformation which, in turn, shaped how humans saw the natural world more generally (Dagognet, 1970: 11-19; Bertrand, 2018a, 2018b). A biology which relies on physics - 'the most fundamental of the sciences'-studies inert objects, elaborates 'laws of nature' and builds machines (Louart, 2018). The next step was to reduce the vegetative strength of plants to economics (Dagognet, 1970). As a result of these changes, plants came to be viewed as an undifferentiated resource, a merely interchangeable element of the economic system. Moreover, the physiocrats and encyclopaedists used the power of botany to redefine agricultural practices and to disregard peasant knowledge (Bertrand, 2018a, 2018b). Western culture has pursued this economic conception of plants with increasing technical efficiency, but without questioning that ideology's very foundations. Contemporary production-centric agriculture has transformed the relationship between humans and the plants they cultivate. It is no longer a collective political relationship, but one in which plants are viewed as a passive resource. In his essay Forests: the shadow of civilization, Robert Harrison illustrates this transformation and the change in scale associated with it:

Descartes [...] sought to empower the subject of knowledge in such a way that, through its application of mathematical method, humanity could achieve 
what he called 'mastery and possession of nature'. One of the ways in which this dream of mastery and possession becomes reality in the post-Christian era is through the rise of forest management during the late-eighteenth and nineteenth centuries. Forests become the object of a new science of forestry, with the State assuming the role of Descartes's thinking subject. Predictably enough, modern forestry reduces forests to their most literal or 'objective' status: timber. A new 'forest mathematics' goes so far as to measure them in terms of their volume of disposable wood. Method thus conspires with the laws of economy to reappropriate forests under the general concept of "utility', even in those cases where utility is conceived in aesthetic terms: forests as recreational parks, for example, or as 'museums' of original nature. Needless to say, we have by no means gotten beyond such conceptions. Enlightenment remains our dominant cultural heritage. (Harrison, 1992: 107-108)

This way of reducing forests to a production tool remains relevant, as seen in a 2018 text published by a forestry cooperative, which declares: 'We dare our politicians to admit that forests are not multifunctional, but that their only economic purpose can meet social needs and environmental requirements!' (Alliance Info, 2018). ${ }^{9}$ In the same vein, the director of the wood sector of a French technological institute explains that, to condition the general public's acceptance of the industrial exploitation of trees, he avoids the term 'forest'. Instead, he substitutes 'woody biomass surface geared toward production'. ${ }^{10}$

\section{Techniques and Technologies}

Since their inception, agronomy and forestry were developed as technical disciplines. Thus, the plant machine thesis has been present since the emergence of plant sciences. Sciences and technologies have evolved and consolidated alongside the notion of living organisms as machines. Moreover, for more than half a century, the technical aspect of human relationships with other living beings became integral to those relationships to an unprecedented degree. This had consequences on knowledge but also on practical outcomes for these organisms (Larrère \& Larrère, 2005). Emblematic of this way of thinking, zootechnics, the science of animal production, is concerned with engineering 'living machines' (Deluermoz \& Jarrige, 2017). In that context, the organism is considered independently of its environment, fragmented into pieces. The perversity of this has not gone unnoticed: 'One might as well study an organism in complete detachment from its environment as try to study an electric clock on the wall in disregard of the wire leading to it' (Dewey \& Bentley, 1949: 139). The mechanical metaphor-especially the reference to the

\footnotetext{
9 Alliance Forêts Bois, the leading forestry cooperative in France, created and managed by private forest owners. https://www.allianceforetsbois.fr/allianceinfos/. Author's translation.

10 Statements collected during an interview as part of an unpublished survey on representations of the plant world, conducted in 2018 among French professionals in plant research and the plant industry.
} 
clock and to clockwork-underlies this absurd, 'sliced' view, which is often applied to cultivated plants.

For example, the 1960s witnessed the development of in vitro culture or micropropagation: a technique that permits the regeneration of a whole plant from a fragment under laboratory-controlled conditions. The modification of external conditions paved the way for the modification of plants by altering internal conditions by means of genetic engineering. At the same time, the study of plant biology used the phytotron, a place in which plants are grown in various environments and in which all climate factors, including light, temperature, humidity, or periodicity, can vary in a controlled way. ${ }^{11}$ The phytotron's name is derived from the cyclotron, a particle accelerator used by experimental physicists.

According to one supporter of 'the phytotronic era',

The pursuit of technological control over organisms and experiments has been and remains a fundamental agent of change for biology in the $20^{\text {th }}$ century. [...] [In a phytotron,] the study of life became an exercise in technological control over both genes and environments and so the knowledge of the machine equalled knowledge of the plant (Munns, 2017).

The 'phytotronic era' invokes the plant machine thesis in a radical way. Such facilities have been promoted in France by the National Centre for Scientific Research (Centre national de la recherche scientifique, CNRS), and, at their launch, were supported by videos using mechanistic allegories. ${ }^{12}$ The term 'phytotron' has fallen into disuse ('ecotron' is a more popular system now), but has been used in about twenty publications per year since the 1980s. ${ }^{13}$

Molecular biology emerged in the twentieth century, as a combination of genetics, biochemistry and physics. At its core, this discipline was built on metaphors from computer science, deliberately transgressing the boundaries between the technological and the biological (Nicholson, 2019). The growing success of molecular biology in biological research has probably resulted in the rapid popularization of the idea of the 'mechanization' of living beings. Our concern is not with the opposition between the artificial and the natural, but rather with the ethical consequences of technical practices, first on plant lives and consequently on whole ecosystems. Molecular biology provided a breakthrough, giving access to an organism's internal conditions and opening possibilities for their modification in a much more direct way than the traditional agricultural techniques of the past, which dealt with whole organisms. Throughout molecular biology, thinking of the plant as a machine very successfully deconstructs organisms into pieces, thereby substantially simplifying the complexity of life itself.

\footnotetext{
11 'Phytotron.' Office québécois de la langue française. Retrieved December 16, 2021. http://gdt.oqlf. gouv.qc.ca/ficheOqlf.aspx?Id_Fiche=26516468.

12 INA, National Audiovisual Institute, video, 1961 'Botany is now joining chemistry' https://www.ina. fr/video/CAF97059044/jean-paul-nitsch-le-phytotron-de-gif-sur-yvette-video.html INA video, 1964, 'A reduced model of what happens in nature' https://www.ina.fr/video/I06199394. The phytotron, CNRS video, 1969, https://videotheque.cnrs.fr/doc $=1342$.

13 Base Web of Science, All databases, topic=phytotron, June 2021.
} 
Is the use of technologies in fields like molecular biology accelerating the conceptualization of living organisms as machines? A telling example is provided by a biotechnology company, Plant Advanced Technologies (PAT®). The company 'explores the world's plant diversity in search of the best active ingredients through a process which aims to harvest plant substances' (Ginglinger, 2018). The company's name is a subtle reference to animals, PAT most likely referring to 'patte', the French word for an animal leg, and they treat plants as items to be 'milked'. PAT's goal is to turn plants into profitable cash cows on La Réunion Island, 'where a $1000 \mathrm{~m}^{2}$ greenhouse [opens] a window to local plant diversity'. Although technology often causes the degradation of diversity, it is presented here as diversity's saviour, while using diversity as an object of production for mainly Western markets. In the same vein, as recently as 2019, a forestry research paper announced that 'Trees are the most efficient and cost-effective carbon capture and storage technology available' (Isabel et al., 2019).

Thus, the animal machine paradigm has been implicitly transformed into a plant machine paradigm: a plant is increasingly seen as 'a soulless mechanical green thing' (Pouteau, 2014). The plant machine thesis has been used by industry with increasing intensity, aiming even at reducing the complex and autonomous characters of the organism's functioning, with its associated milieu, to the simplest technical object, as uniform and heteronomous as possible. This process has proven to be useful to the scientific understanding of living organisms as a method of investigation and understanding of many phenomena. However, the problem lies in an ideology that transforms a method of scientific investigation into an ontological and ethical discourse on the very nature of living beings - especially on plants. Confusing the model and the subject of inquiry gives this amalgam a normative value. If a plant can be understood through a machine functioning model, the reasoning goes, then the plant may also be reduced to the same kind of mere and pure machine. We must become aware of the ontological and ethical posture which our society seems to have unquestioningly inherited from this mechanizing trend.

\section{Plants and Humans}

The continuous modification of plants to suit human needs-referred to as "plant breeding' or 'plant improvement'-is as old as plant cultivation itself, beginning with the domestication of the first agricultural plants. Of course, the techniques used for such modifications have evolved through history.

In a theoretical work on plant genetics, which addresses how variety is created among cultivated plants-how they are selected and improved (note that this term suggests that plants are 'imperfect')—Gallais (1989) thoroughly embraces the plant machine thesis. Plant improvement is defined as a "science [...] increasingly responding to human needs', through which people may obtain 'well "balanced" and adapted plants.' 'To understand the plant-environment dialogue,' the author suggests that 'deciphering all the genetic information of a plant would be necessary', a goal which he calls 'quite unrealistic' (Gallais, 1989: xi-xii). Today, complete genomes have been sequenced, beginning with the human genome in the early 
2000s, followed soon after by the genomes of more than 550 species of higher plants sequenced to date. ${ }^{14}$ The objective of identifying 'all genetic information' might seem to have been achieved, because the whole sequence of DNA nucleotides specific to each species has been decoded. However, two decades later, these sequences still struggle to account for the complex phenotype of living things, particularly plants (Sultan, 2015).

Selection, which starts from a small sample of individuals chosen from wild populations, produces conscious or unconscious modifications to biological species through practices such as tillage, seed choice and selective harvesting. The goal of these practices is to improve plants so that they produce organs (like seeds, stems, leaves, tubers or berries) suited for human use. The modified traits which are noticeable to human senses include speed of growth, size, colours, toxicity and nutritional content. The unnoticed traits include dormancy, mineral nutrition physiology, root systems and metabolic chains (David, 2017). Teosinte-a wild plant with multiple long stems and ears containing wrapped kernels-is very different from its domesticated sister species, maize, with its single stem and ears filled with naked kernels. The latter can be seen as a 'well-packaged, high-yielding, and easily harvested agricultural artifact' (Raven et al., 2013: 510): in short, a technical object.

Although all machines are technical objects, not all technical objects are machines. A machine is a complex technical object with a systematic organization of parts and a certain autonomy of operation (although its functioning can be largely programmed). A technical object, on the other hand, may be very simple and heteronomous, like a nail, a screw or a hammer, for example.

The use of plant breeding in industrial agriculture has created an extreme situation in which each fruit and vegetable must be as perfectly calibrated as a manufactured product. A plant variety must programmatically ${ }^{15}$ provide the farmer with a defined yield in tons per hectare and precise product characteristics, just like a highperformance industrial production tool. However, even an individual plant can present variations. For example, an apple tree can bear apples of different sizes (Herrera, 2009). For economic and practical reasons, the cultivation of a plant species is a search for uniformity and homogeneity, which turns the plant into an industrial technical object. For example, chocolate manufacturers prefer cocoa beans of uniform size, which may be processed more efficiently. Likewise, a variation in the size of oat kernels is costly for the oat-milling industry. Variation between individual plants of the same species, which can be significant in species grown for fruit or seed, has always been considered a nuisance by agronomists, who have worked to reduce it (Herrera, 2009). Variability and variations among individuals enable species to adapt to their environments, and therefore represent a kind of autonomy for

\footnotetext{
14 'Published Plant Genomes', Forschungszentrum Jülich. Retrieved December 16, 2021. https://www. plabipd.de/plant_genomes_pa.ep.

15 Some contracts between agri-food manufacturers and farmers who provide raw materials indeed go so far as to ask for financial compensation from the farmers in case of a natural disaster reducing the planned production: https://www.sillonbelge.be/5696/article/2020-03-19/relation-avec-lagro-industriequelques-cles-pour-un-contrat-equilibre-et-sans.
} 
organisms. However, they must be curtailed for 'products' to comply with the constraints of the heteronomous and stable industrial use of these 'technical objects'.

Cultivated varieties of cassava and banana have lost their sexuality. ${ }^{16}$ Instead, they are propagated by cuttings. Therefore, their survival depends exclusively on humans. At the individual level, they are almost completely homogenous. Current varieties of many other cultivated plants are also characterized by extreme genetic homogeneity: all individuals are nearly identical. Individuals propagated through vegetative reproduction are perfect genetic duplicates of their forebears. But sexual reproduction in which individuals are created by cross breeding genetically identical lines are therefore homogeneous as well. However, as cultivated species and their varieties exhibit visible (phenotypic) diversity, they also lose genetic diversity compared to wild populations, a situation described as Darwin's paradox (Glémin \& Bataillon, 2009). Plant species are deeply transformed by selection processes, which 'scare' them and make them 'lose their head' (Gerber, 2018). They are 'assisted monsters’ (Bournérias \& Bock, 2006: 202-203), just like domesticated animals:

Domestic animals are abnormal, irregular, artificial [...]: their very existence depends altogether on human care; so far are many of them removed from that just proportion of faculties, that true balance of organization, by means of which alone an animal left to its own resources can preserve its existence (Wallace, 1858 cited in Sniadecki, 2011)

If there is a similarity between domesticated animals and cultivated plants, it is the latter, possessing large species diversity and plasticity, which are more intensively manipulated in all aspects of their lives, as all of their vital features are overseen by their human masters. Moreover, the capitalist industrialization of agriculture has serious consequences for terrestrial ecosystems, on a much larger scale than animal husbandry (Marder, 2013). Some philosophers and anthropologists have captured the centrality of plant life on Earth by qualifying our era as the 'Plantationocene' or 'Planthropocene', rather than the Anthropocene (Haraway, 2015; Tsing, 2015; Myers, 2017). In the same vein, contemporary philosophers argue that the centrality of plant lives' associations with the lives of humans and all other species throughout earthly environments has significant consequences for our traditional ontology (Coccia, 2016; Hache, 2011; Marder, 2014).

\section{Legal and Ethical Consequences}

Plants are living organisms. They are sensitive and, in a sense, rational. Consistently treating them as such could complicate the relationship between plants and humans-which perhaps explains our failure to do so. Traditional ethics and the modern legal system have developed strategies to dismiss or simplify relationships with — and avoid responsibilities towards - the plant world. Thus, proponents of the patentability of living matter have strategically suppressed the legally undefined and

${ }^{16}$ Banana trees are said to be parthenocarpic because they produce seedless fruits without fertilization. 
ambiguous vocabulary of 'living', promoting in its place a technical vocabulary and technical vision (Hermitte, 2016). Living beings are classified as 'biological matter', defined as 'containing genetic information which is self-replicating or reproducible in a biological system'. This definition frames the genes and cells of all the living kingdoms as 'technical objects'. The living world may as well be pieces in a toy building set:

a plant defined by single recombinant DNA sequences [...] is not a concrete living being [...] but an abstract and open definition embracing an indefinite number of individual entities defined by a part of its genotype or by a property bestowed on it by that part (EPO, European Patent Office, quoted by Hermitte, 2016: 48).

So, thanks to the cumulative nature of life, patents can be endlessly multiplied. The unquestioned Western philosophical heritage which posits a radical discontinuity between animals (including humans) and plants thus allows the almost limitless modification and patenting of genetically modified plants, whereas a similar practice with respect to animals arouses much greater opposition. However, this disparate treatment has no evolutionary, genetic, physiological or ecological justification.

When a biological research project proposal is submitted to a funding body, the application usually includes questions about ethics. If the project intends to study vertebrates, the ethics question is essential. If the organism to be studied is phylogenetically distant from humans, this part is relatively unimportant. For studies of plants, fungi or bacteria, in contrast, this question is cursory or simply non-existent. The fact that most biologists have no background in ethics does not help. The moral attitude that prioritizes human interests over those of the rest of the living world should not lead us to exempt those of our actions which affect non-animal living organisms_-plants, fungi, or bacteria-from ethical scrutiny. The animal kingdom's ethical priority over others is generally justified by animals' unique capacity to suffer. However, many animals, instead of a central nervous system, have much more general mechanisms of sensitivity. As we have argued in Sect. 3.1, the same is true of plants. The persistence of clearly defined, exclusive categories like 'animals' versus 'plants' in most contemporary ethical reasoning could evolve thanks to advances in present evolutionary knowledge. Sensitivity alone does not suffice to clearly distinguish between living beings. The pain criterion, adapted to animals, excludes the huge group of non-suffering organisms from ethical consideration. On the other hand, the fact that all organisms, including plants, have a form of instrumental rationality, as we discussed in Sect. 3.2, does not imply that all organisms deserve the same ethical treatment. The diversity of life forms makes wide-ranging ethical strategies ineffective, especially if they are based on the universalization of a single criterion. Inevitably, such strategies will unduly relegate certain individuals from the sphere of ethical consideration, into the realm of machines or technical objects. Only a relational ethics could accurately track the plurality of humanplant relationships. Many people do not recognize plants to be sensitive and (in some sense) rational organisms, probably because they are a useful resource for humans to breed, alter and consume. But, even despite this wilful blindness, 
the links between humans and plants are not purely theoretical: they are reciprocal, social, and inscribed in a long shared history (Degnen, 2009). The history of human civilization is deeply marked by plant domestication, a practice which has intertwined and interconnected human and plant life forms (Degnen, 2009; Lieutaghi, 1998; Pouteau, 2018). If we define agency as 'the power of an individual, subject to a dominant power, to act' (Brunon, 2015), plants manifest their agency not only through behavioural rationality but also through these inter-species relationships.

In Switzerland, the Federal Ethics Committee on Non-Human Biotechnology reflected on the ethical treatment of plants. In particular, the committee was interested in the dignity and inherent worth of these living organisms, and whether they ought to be protected and considered morally for their own sake. The debate continued elsewhere, especially in German-speaking countries (Koechlin, 2009; Lev-Yadun, 2008; Pouteau, 2014). The Swiss commission concluded that 'recent findings in natural science, such as the many commonalities between plants, animals and humans at molecular and cellular level' in principle justify including plants in the moral community (CENH, 2008). The instrumental value of plants, including the services they provide to ecosystems, as crops or otherwise, which benefit humans and other organisms, should not obscure the other values of plants. Their relational value is equally important. That value is related to enjoyable properties of plants, such as their aesthetic quality. But this is not all that makes them worthy of protection. Respecting the 'dignity' of plants, the commission argued, demands considering the intrinsic value of their lives, their own inherent worth, according to their own sensitivity and interests. 'What is decisive for the respect of dignity' they argued, 'is that an entity is not treated solely as a means to an end' (CENH, 2008), or, in other words, a being is respected when it is not treated like a machine. Practical and ethical recommendations have recently been developed specifically for plants (Hiernaux, 2021a, 2021b; Kallhoff et al., 2020).

The technological, industrial thinking about plants is exemplified by the widely used notion of 'ecosystem services'. These refer to the direct and indirect goods and services, generally measured by their monetary value, which elements of the environment, including plants, are supposed to provide (Boisvert, 2016). Integrating nature into the economic market like this reinforces the idea that plants, like farm animals, are mere consumer goods (Deluermoz \& Jarrige, 2017), rather than individuals with singularities, intrinsic value, dignity, or relational value forged through their links with other organisms and their environments. Western civilization's relationship with plants has remained stable since modern times, while our relationship with animals has evolved significantly. Changes in the latter include the emotional bond developed through domestication, the replacement of animal power with mechanical instruments during the Industrial Revolution and intensive animal breeding. The extinction of animal species also routinely causes public outcry, legal action and condemnation from active non-governmental organisations dedicated to animal protection. Similar attitudinal shifts and public actions concerning plants remain less important. 


\section{Conclusion}

The vision of a mechanized living world explicable wholly by the laws of physics is typical of the modern era. It has existed at least since Descartes and his heirs, some radical enough to call animals machines, and remains central to our thinking about the plant world. We have shown that treating plants as machines is problematic. Neither the radical organism machine thesis, that plants are fully devoid of sensitivity, nor the moderate thesis, that plants are devoid of any form of reason, stands up to scrutiny. In fact, contrary to persistent historical prejudices, contemporary science recognizes the sensitivity of plants, as sensitivity does not require a nervous system. While this does not imply that plants suffer or feel emotions, it is enough to undermine the radical thesis. Similarly, recent experiments on plants indicate that they remember and learn, which allows them to choose from among alternatives when solving problems, as when vines evaluate and select potential supports. Plants' capacity to evaluate situations and make decisions represents a species of rationality. Even though plants are not conscious and probably do not represent their chosen actions to themselves, their instrumental rationality reveals another weakness in the moderate plant machine thesis. Nonetheless, the thesis often remains implicit and unquestioned in contemporary biology, agricultural science and technology. In recent years, the way plants are studied has evolved, modifying how humans understand plants, both on their own and in their relationships with other living things. Several contemporary research avenues dedicated to discerning the different aspects of plant intelligence and their capacity to communicate have emerged (Bertrand, 2018a, 2018b, 2020a; Chouchan, 2018). Beyond the mechanistic approach, even the general idea of an 'organism' is problematic in its application to plants and should be revised. The common model of the organism is just that of an animal: a centralized body containing vital organs. Plants, in contrast, are bodies which lack vital organs, and with no predefined, enclosed, centralised space, hence without a topos. Instead, their functions are distributed and decentralized. In short, they are open beings (Pouteau, 2014).

Biology continues to consider plants with a mechanistic approach. This method can advance our knowledge of plant functioning. However, if such an abstract and reductionist approach 'forgets' to return to the whole living plant (Dewitte, 2002), it limits the quality of extending possible ethical considerations. It does this by ignoring the complexity of living plants, their immense diversity, the many different ways plants interact with other living beings-including humans-and with the environment.

Often, technological innovation encourages a view of plant functioning that ignores our social links to plants, to their capacities and to their vitality. Western rationality tries to shape a quantitative reality, to control and to tame life. Machines represent a colonization of the living. In a machine, the real is divided into tractable, discontinuous elementary units. When the mechanized conception overlays living beings, such as plants, it becomes a new environment, a system with its own logic (Ellul, 1976). By treating life forms as assemblies 
of mechanical modules, that conception obliterates their reality as wholes that evolve through internal and external relationships (Benasayag, 2018, quoted by Guillaud, 2019). Manipulating genetics through cross breeding, selection and direct DNA alteration, with the goal of creating plant varieties-'distinct, uniform and stable' biological types (Baril, 2001)_amounts to coercion for the benefit of large industrial markets. These processes have led to a reduction in the diversity of cultivated plant species for the sake of better performance, predictability and control (Bonneuil, 2016). Standardization suits business interests which intend to capture and monetize the common good embodied by the diversity of cultivated plants (Bonneuil \& Thomas, 2009).

Technological industrial rationality creates its own values and its own ontology, perpetuating its own particular way of covering the world (Ellul, 1976). It denies agency and distinctness to living organisms - plants in particular. When it stands as a normative ideology, classical scientific methodology can be a threat, because what it 'touches dries up and dies, dies to qualitative diversity, to singularity, to become the simple consequence of a general law' (Prigogine \& Stengers, 1979 quoted by Amzallag, 2003). By questioning or rejecting mechanistic views in ethics, we can rethink the diversity, quality and intensity of our connections with plants, and build new ways of understanding and inhabiting the world (Javelle et al., 2020).

Acknowledgements We thank Juliette Archambeau, Cyril Firmat, the Émile Durckheim lab (University of Bordeaux) "Atelier environnement et capitalisme", Didier Alard, Jérôme Santolini, Benoît Timmermans, Sarah Benharech, Thierry Labbé, Elis Jones and an anonymous reviewer for its useful comments.

Authors' Contributions Both authors contributed equally to all aspects of the article.

Funding This work was supported by the National Fund for Scientific Research (FNRS postdoctoral fellowship no 32740322) and by the National Research Institute for Agriculture, Food and Environment-INRAE.

Availability of Data and Materials Not applicable.

Code Availability Not applicable.

\section{Declarations}

Conflict of interest The authors have no relevant financial or non-financial interests to disclose.

\section{References}

Allen, C., \& Trestman, M. (2020). Animal consciousness. In E. N. Zalta (Ed.) The Stanford Encyclopedia of philosophy (Winter 2020 Edition). Retrieved July 6, 2021, from https://plato.stanford.edu/archi ves/win2017/entries/consciousness-animal/.

Alliance Infos. (2018) 14. Retrieved July 6, 2021, from https://www.allianceforetsbois.fr/allianceinfos/. Amzallag, G. N. (2003). L'Homme Végétal. Pour une autonomie du vivant. Albin Michel.

Andrews, K. (2016). Animal cognition. In E. N. Zalta (Ed.), The Stanford Encyclopedia of philosophy (Winter 2017 Edition). Retrieved July 6, 2021, from https://plato.stanford.edu/archives/sum2016/ entries/cognition-animal/. 
Andrews K., \& Monsó, S. (2021). Animal cognition. In E. N. Zalta (Ed.), The Stanford Encyclopedia of philosophy (Spring 2021 Edition). Retrieved July 6, 2021, from https://plato.stanford.edu/archives/ spr2021/entries/cognition-animal/.

Andrews, K. (2020). How to study animal minds. Cambridge University Press.

Aydede, M., (2019). Pain. In E. N. Zalta (Ed.), The Stanford Encyclopedia of philosophy (Spring 2019 Edition). Retrieved July 6, 2021, from https://plato.stanford.edu/archives/spr2019/entries/pain/.

Baldassarri, F. (2019). The mechanical life of plants: Descartes on botany. The British Journal for the History of Science, 52(1), 41-63.

Baril, C. (2001). Caractérisation variétale. Les marqueurs moléculaires: Un nouvel outil pour l'inscription et la protection variétale? Oléagineux, Corps Gras, Lipides, 8(5), 502-505.

Bechtel, W., \& Bich, L. (2021). Grounding cognition: Heterarchical control mechanisms in biology. Philosophical Transactions of the Royal Society B. https://doi.org/10.1098/rstb.2019.0751

Benasayag, M. (2018). Fonctionner ou exister. Le Pommier.

Benharrech, S. (2022). Trees as dividual beings: Vegetal plurality in early modern France. Voyage to the Island of Mauritius (or Isle de France) (1773), Henri-Bernardin de Saint-Pierre (1737-1814). In N. Meeker, \& A. Szabari (Eds.), Special Issue of L'Esprit créateur on 'Libertine Botany'. Forthcoming in winter 2022.

Bernier, G. (2013). Darwin un pionnier de la physiologie végétale. L'apport de son fils Francis. Académie royale de Belgique.

Bertrand, A. (2018a). Le blé des physiocrates. Contribution à une histoire politique de l'ontologie végétale. Cahiers Philosophiques, 152, 9-36.

Bertrand, A. (2018b). Penser comme une plante: Perspectives sur l'écologie comportementale et la nature cognitive des plantes. Cahiers Philosophiques, 153(2), 39-41.

Bertrand, A. (2020a). Sociabilités végétales? Sens-Dessous, 26(2), 41-49.

Bertrand, A. (2020b). «Elle sera donc odeur de rose, d'oeillet, de jasmin, de violette»: l'attention au végétal et l'institution des collectifs, de Condillac à Descola et retour. Anthropologie Et Sociétés, 44(3), $109-128$.

Bitbol-Hespériès, A. (1990). Le principe de vie chez Descartes. Vrin.

Blay, M. (Ed.). (2012). Grand dictionnaire de la philosophie. CNRS éditions.

Boisvert, V. (2016). Des limites de la mise en marché de l'environnement. Écologie Et Politique, 52, 63-79.

Bonneuil, C. (2016). Pure lines as industrial simulacra: A cultural history of genetics from Darwin to Johannsen'. In S. Mueller-Wille \& C. Brandt (Eds.), Heredity explored. Between public domain and experimental science, 1850-1930 (pp. 213-242). MIT Press.

Bonneuil, C., \& Thomas, F. (2009). Gènes, pouvoirs et profits: Recherche publique et régimes de production des savoirs de Mendel aux OGM. Quæ; Fondation pour le progrès de l'homme.

Bournérias, M., \& Bock, C. (2006). Le génie des végétaux. Des conquérants fragiles. Belin.

Brunon, H. (2015). L'agentivité Des Plantes. Vacarme, 73(4), 118-123. https://doi.org/10.3917/vaca.073. 0118 .

Burgat, F. (2006). Liberté et inquiétude de la vie animale. Kimé.

Burgat, F. (2020). Qu'est-ce qu'une plante? Seuil.

Canguilhem, G. (1965). Knowledge of life. Fordham University Press.

Carruthers, P. (2008). Meta-cognition in animals: A skeptical look. Mind \&amp; Language, 23, 58-89.

CENH. (2008). The dignity of living beings with regard to plants. Moral consideration of plants for their own sake. Retrieved July 6, 2021, from https://www.ekah.admin.ch/en/topics/dignity-of-livingbeings/\#c663.

Cesalpino, A. [1583] (2021). De Plantis Libri XVI. In Q. Hiernaux (Ed)., Textes-clés de Philosophie du végétal. Vrin.

Chouchan, N. (2018). Éditorial. Cahiers Philosophiques, 153(2), 5-8.

Coccia, E. (2016). La vie des plantes. Une métaphysique du mélange. Payot et Rivages.

Cvrcková, F., Lipavská, H., \& Žárský, V. (2009). Plant intelligence: Why, why not or where? Plant Signaling and Behavior, 4, 394-399.

Dagognet, F. (1970). Le catalogue de la vie. PUF.

Dagognet, F. (1988). La maîtrise du vivant. Hachette.

Darwin, C. (1865). On the movements and habits of climbing plants. Journal of the Linnean Society of London (botany), 9, 1-118.

David, J. (2017). La domestication des plantes à l'échelle de la génomique. Jardins De France, 646, $13-16$. 
Davy de Virville, A., \& Leroy, J. F., et al. (1969a). Botanique à la Renaissance. In R. Taton (Ed.), La science moderne de 1450 à 1800 (pp. 177-187). Presses Universitaires de France.

Davy de Virville, A., \& Leroy, J. F., et al. (1969b). Botanique au XVIIIe siècle. In R. Taton (Ed.), La science moderne de 1450 à 1800 (pp. 677-697). Presses Universitaires de France.

de Condillac, E. B. (1792). Traité des sensations, suivi du Traité des animaux [1755]. Les libraires associés.

de La Mettrie, J. O. [1748] (1996). Man as a plant. In A. Thomson (Ed.), Machine man and other writings (pp. 75-88). Cambridge University Press.

de Montaigne, M. [1580] (1877). Essays. William Carew Hazlitt, ed. Retrieved July 6, 2021, from https:// www.gutenberg.org/files/3600/3600-h/3600-h.htm\#link2HCH0068.

Debono, M. W. (Ed.). (2020). L'intelligence des plantes en question. Hermann.

Degnen, C. (2009). On vegetable love: Gardening, plants, and people in the north of England. Journal of the Royal Anthropological Institute, 15(1), 151-167.

Delaporte, F. [1979] (1982). Nature's second Kingdom. Explorations of vegetability in the eighteenth century. MIT Press.

Deluermoz, Q., \& Jarrige, F. (2017). Introduction. Écrire l'histoire avec les animaux. Revue D'histoire Du XIXe, 54, 15-29. https://doi.org/10.4000/rh19.5180.

Descartes, R. (1637). Discours de la méthode (1637), Paris, Le Cerf (Adam et Tannery), 1902.

Descartes, R. (1638). Letter to Plempius, Feb 15, 1638.

Descartes, R. (1646). Lettre au marquis de Newcastle du 23 novembre 1646.

Descartes, R. (1647). Les principes de la philosophie (1647), Paris, Vrin, 1970.

Descartes, R. (1649). Lettre à Morus, Feb 5, 1649.

Dewey, J., \& Bentley, A. F. (1949). Knowing and the known. Beacon Press.

Dewitte, J. (2002). L'anthropomorphisme, voie d'accès privilégiée au vivant. L'apport de Hans Jonas. Revue Philosophique De Louvain, 100(3), 437-465.

Ellul, J. (1976). (2004). La technique considérée en tant que système. Cahiers Jacques Ellul, Dossier: La Technique, 2, 49-66.

Francione, G. (2000). Introduction to animal rights: Your child or the dog? Temple University Press.

Gagliano, M., Renton, M., Depczynski, M., \& Mancuso, S. (2014). Experience teaches plants to learn faster and forget slower in environments where it matters. Oecologia, 175(1), 63-72.

Gagliano, M., Vyazovskiy, V. V., Borbély, A. A., Grimonprez, M., \& Depczynski, M. (2016). Learning by association in plants. Scientific Reports, 6, 38427.

Gallais, A. (1989). Théorie de la sélection en amélioration des plantes. Masson.

Gaukroger, S. (1995). Descartes: An intellectual biography. Clarendon Press.

Georges-Berthier, A. (1914). Le mécanisme cartésien et la physiologie au XVII ${ }^{\mathrm{e}}$ siècle. Isis, 2(1), 37-89.

Gerber, S. (2018). Les plantes cultivées cachent-elles la forêt? In Q. Hiernaux \& B. Timmermans (Eds.), Philosophie du végétal (pp. 91-114). Vrin.

Ginglinger, J. F. (2018). PAT: les plantes que l'on peut traire. Conférence à l'Institut de botanique, Strasbourg.

Glémin, S., \& Bataillon, T. (2009). A comparative view of the evolution of grasses under domestication. New Phytologist, 183(2), 273-290. https://doi.org/10.1111/j.1469-8137.2009.02884.x

Gruen, L. (2021). The moral status of animals. In E. N. Zalta (Ed.), The Stanford Encyclopedia of philosophy (Summer 2021 Edition). Retrieved July 6, 2021, from https://plato.stanford.edu/archives/ sum2021/entries/moral-animal/.

Guattari, F. (1993). Chaosmose. Galilée.

Guerra, S., Peressotti, A., Peressotti, F., et al. (2019). Flexible control of movement in plants. Science and Reports, 9, 16570.

Guichet, J. L. (Ed.). (2010). De l'animal machine à l'âme des machines - querelles biomécaniques de l'âme (XVIIe/XXIe siècles). Publications de la Sorbonne.

Guillaud, H. (2019). Défaire la tyrannie du numérique? Retrieved July 6, 2021, from http://www.inter netactu.net/2019/10/23/defaire-la-tyrannie-du-numerique/.

Hache, É. (2011) Ce à quoi nous tenons - Propositions pour une écologie pragmatique. Les Empêcheurs de penser en rond, Éditions La Découverte.

Hall, M. (2011). Plants as persons. SUNY Press.

Haraway, D. (2015). Anthropocene, capitalocene, plantationocene, chthulucene: Making kin. Environmental Humanities, 6, 159-165.

Harrison, R. (1992). Forests: The shadow of civilization. The University of Chicago Press.

Hegel, G. W. F. [1830] (2002). Philosophy of nature. Routledge. 
Hermitte, M. H. (2016). L'emprise des droits intellectuels sur le monde vivant. Éditions Quæ.

Herrera, C. M. (2009). Multiplicity in unity. University of Chicago Press.

Hiernaux, Q. (2019). History and epistemology of plant behaviour: A pluralistic view? Synthese, 198(4), $3625-3650$.

Hiernaux, Q. (2020). Du comportement végétal à l'intelligence des plantes? Quæ.

Hiernaux, Q. (2021a). Differentiating behaviour, cognition, and consciousness in plants. Journal of Consciousness Studies, 28(1-2), 106-135.

Hiernaux, Q. (2021b). The ethics of plant flourishing and agricultural ethics: Theoretical distinctions and concrete recommendations in light of the environmental crisis. Philosophies, 6, 91. https://doi.org/ 10.3390/philosophies6040091.

Isabel, N., Holliday, J. A., \& Aitken, S. N. (2019). Forest genomics: Advancing climate adaptation, forest health, productivity, and conservation. Evolutionary Applications, 13, 3-10.

Javelle, A., Kazic, D., \& Tassin, J. (2020). Special issue "Repenser le statut des plantes". La pensée écologique, 2(6).

Kallhoff, A., Di Paola, M., \& Schörgenhumer, M. (Eds.). (2020). Plant ethics. Routledge.

Koechlin, F. (2009). The dignity of plants. Plant Signaling \&amp; Behavior, 4(1), 78-79.

Kolodny, N., \& Brunero, J. (2020). Instrumental rationality. In E. N. Zalta (Ed.), The Stanford Encyclopedia of philosophy (Spring 2020 Edition). Retrieved July 6, 2021, from https://plato.stanford.edu/ archives/spr2020/entries/rationality-instrumental/.

Kreutzer, M. (2017). L'éthologie. PUF.

Lalande, A. (1996). Vocabulaire technique et critique de la philosophie. PUF.

Larrère, C. (1992). L'invention de l'économie au XVIIIe siècle; Du droit naturel à la physiocratie. PUF.

Larrère, C., \& Larrère, R. (2005). Actualité de l'animal-machine. Les Temps Modernes, 2-3(630-631), 143-163.

Lev-Yadun, S. (2008). Bioethics: On the road to absurd land. Plant Signaling \&amp; Behavior, 3(8), 612.

Lieutaghi, P. (1998). La plante compagne. Actes sud.

Locke, J. (1690). An essay concerning humane understanding (2nd ed.). Thomas Basset.

Louart, B. (2018). Les êtres vivants ne sont pas des machines. Collection Notes et morceaux choisis, La Lenteur. http://www.hobo-diffusion.com/catalogue/1664/notes-et-morceaux-choisis-13-notes-etmorceaux-choisis.

Maher, C. (2017). Plant minds: A philosophical defense. Routledge.

Mancuso, S., \& Viola, A. (2015). Brilliant green. Island Press.

Marder, M. (2013). Is it ethical to eat plants? Parallax, 19(1), 29-37.

Marder, M. (2014). For a phytocentrism to come. Environmental Philosophy, 11(2), 237-252.

Munns, D. P. (2017). Engineering the environment: Phytotrons and the quest for climate control in the cold war. University of Pittsburgh Press.

Myers, N. (2017). From the anthropocene to the planthroposcene: Designing gardens for plant/people involution. History and Anthropology. https://doi.org/10.1080/02757206.2017.1289934.

Nicholson, D. J. (2019). Is the cell really a machine? Journal of Theoretical Biology, 477, 108-126.

Olson, E. A., \& Stepp, J. R. (Eds.). (2016). Plants and health-New perspectives on the health-environment-plant Nexus. Springer.

Olson, R. (1990). Science defied and science deified: The historical significance of science in western culture. University of California Press.

Pouteau, S. (2014). Beyond 'second animals': Making sense of plant ethics. Journal of Agricultural and Environmental Ethics, 27(1), 1-25.

Pouteau, S. (2018). Plants as open beings: From aesthetics to plant-human ethics. In A. Kallhoff, M. Di Paola, \& M. Schörgenhumer (Eds.), Plant ethics (pp. 82-97). Routledge.

Prigogine, I., \& Stengers, I. (1979). La Nouvelle Alliance. Gallimard.

Raja, V., Silva, P. L., Holghoomi, R., et al. (2020). The dynamics of plant nutation. Science and Reports, 10, 19465.

Raven, P., Evert, R., \& Eichorn, S. (2013). Biology of plants (8th ed.). Freeman and Company.

Renck, J.-L., Servais, V. (2002). L'éthologie. Histoire naturelle du comportement. Seuil.

Rousseau, J. J. [1776-1778] (1972). Les rêveries du promeneur solitaire. Gallimard.

Sauvagnargues, A. (2012). Machines, comment ça marche? Chimères, 2(77), 35-46.

Scarantino, A., \& de Sousa, R. (2021). Emotion. In E. N. Zalta (Ed.), The Stanford Encyclopedia of philosophy (Summer 2021 Edition). Retrieved July 6, 2021, from https://plato.stanford.edu/archives/ sum2021/entries/emotion/.

Simondon, G. (1958). Du mode d'existence des objets techniques. Aubier. 
Simonetti, V., Bulgheroni, M., Guerra, S., et al. (2021). Can plants move like animals? A three-dimensional stereovision analysis of movement in plants. Animals, 11, 1854.

Sniadecki, A. (2011). Malhonnêtetés et Fraudes de Darwin. Retrieved July 6, 2021, from https://sniad ecki.wordpress.com/2011/04/02/critique-darwin-1/.

Sultan, S. (2015). Organism and environment: Ecological development, niche construction, and adaptation. Oxford University Press.

Thellier, M. (2015). Les plantes ont-elles une mémoire? Quæ.

Trewavas, A. (2014). Plant behaviour and intelligence. Oxford University Press.

Trewavas, A., Baluška, F., Mancuso, S., \& Calvo, P. (2020). Consciousness facilitates plant behavior. Trends in Plant Science. https://doi.org/10.1016/j.tplants.2019.12.015.

Uexküll, J. [1934] (1965). Mondes animaux et monde humain. Denoël.

von Linné, C. [1736] (2005). Fondements botaniques, qui, comme Prodrome à de plus amples travaux livrent la théorie de la science botanique par brefs aphorismes. Vuibert.

Wallace, A. R. (1858). On the tendency of varieties to depart indefinitely from the original type. Paper on natural selection sent by Wallace to Darwin. Retrieved July 6, 2021, from http://wallace-online.org/ content/frameset?pageseq $=1 \&$ itemID $=$ S043\&viewtype $=$ text.

Publisher's Note Springer Nature remains neutral with regard to jurisdictional claims in published maps and institutional affiliations. 